\title{
Importance of the Islands in Karun River in Ahvaz City for Birds
}

\author{
Behrouz Behrouzi-Rad* \\ Department of Environment, Ahwaz Branch, Islamic Azad University, Ahwaz, Iran
}

Submission: June 23, 2017; Published: July 25, 2017

*Corresponding author: Behrouz Behrouzi-Rad, Department of Environment, Ahwaz Branch, Islamic Azad University, Ahwaz, Iran, Email: behrouzirad@yahoo.com

\begin{abstract}
Ecological aspects of birds in and around of Karun River islands were conducted during April to September 2014. Data collection was made every month during study period. This study assessed the species composition relative abundance and species diversity of avifauna found in terrestrial habitats and water body at around of Islands. A total of 57 species, 28 families and 12 orders were identified. Family Ardeidae had the highest number of bird species (six species) followed by Ploceidae and Columbidae (five species each), Sylvidae (four species) Meropidae, and Apudidae (three species each) and other family one species each. Terrestrial habitat of islands had the high species number, abundance and diversity compared to aquatic habitat. Shannon's diversity index indicated that terrestrial habitat had higher species diversity $\left(H^{\prime}=2.2745\right)$ than aquatic habitat $\left(H^{\prime}=2.2379\right)$. The study shows that habitat destruction due to anthropogenic activities including expansion of settlements, agriculture, fishing and livestock grazing were the main threats to the survival of the birds in and around islands. A total of 57 species of birds representing 20 species of wetland birds and 37 species of terrestrial birds were recorded during the study period. Due to occurrence of relatively higher number of wetland bird species, Karun river islands may be consider the real place for the bird watchers and should be conserved longer existence.
\end{abstract}

Keywords: Species diversity; Density; Birdwatchers; Karun River Islands

\section{Introduction}

The highest number of water birds is often found in wetlands which have the greatest diversity of plant species and vegetation types, or where there is permanent water Balla, [1]. During the hot summer months the larger permanent wetlands on the Swan Coastal Plain play an important role in providing a drought-refuge for several species of water bird. Herons stalk the shallows, snipe feed in the long grass at the water's edge while grebes, ducks and cormorants feed in the open water. The provision of feeding and roosting habitat is very important for migratory species which in some cases migrate many thousands of kilometers. In recognition of the significance of wetlands for many trans-equatorial species of migratory water bird, several wetlands in the Khouzestan have been identified as being internationally significant under the Ramsar Convention.

The Ramsar Convention (Convention on Wetlands of International Importance, especially as Waterfowl Habitat) is an international treaty that was adopted in Ramsar, Iran in 1971 to provide for international support and cooperation to protect and conserve wetland habitats. Most of island in Karun River have wetland condition. Permanent water of Karun River around of them flowed every time, food (fishes and other aquatic organisms) vegetation cover produce seed, and foods for herbivores birds, refuge and nesting place for terrestrial birds. Some of islands are used as breeding sites for a number of species that nest on the ground. Waders and terns also commonly use these areas as roosts for 'loafing'. A good knowledge of water bird habitat requirements will enable you to encourage water birds in urban or rural areas. The Karun River Island situated in Ahwaz city and are very important for breeding and non-breeding birds. Aim of this study is to show the density and diversity of birds that use these islands.

\section{Methods and Materials}

This study was carried out in and around Karun River Islands (Figure 1) which is situated in Ahwaz city district (latitude $05^{\circ} 57^{\prime} .04^{\prime \prime} \mathrm{S}$ and longitude $35^{\circ} 58^{\prime} 09^{\prime \prime} \mathrm{E}$ )

\section{Field data collection}

Water bird species were recorded by direct observation in water body. Terrestrial birds' observations were carried out by walking slowly along islands. Birds were counted as bird seen and heard and birds in flight were also recorded. 


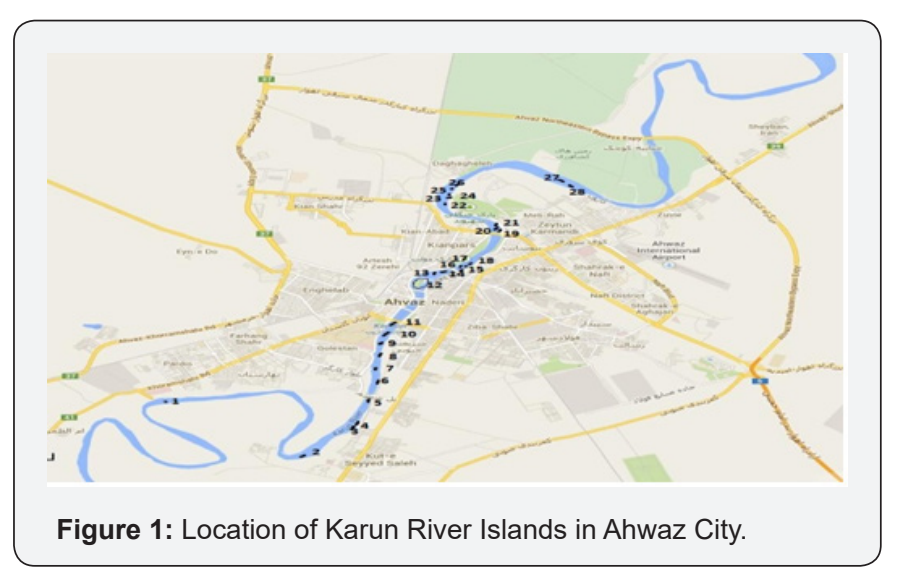

\section{Data analysis}

The relative abundance of a species was obtained by dividing the abundance of a species by the total abundance of all species combined based on the assumption that the frequently seen the species the more abundant it is Bibby et al. [2]. Birds' diversity was calculated using both Shannon-Weiner and Simpson's diversity indices. Shannon-Weiner diversity Index ' $\mathrm{H}$ ' was

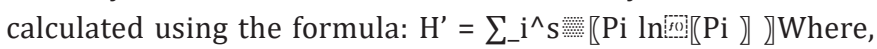
$\mathrm{Pi}=$ Proportion of individual species and $\mathrm{R}=$ total number of species of the community (number seen and heard). Simpson's diversity Index 'D' was calculated using the formula: $D=\left(\sum\right.$ mi $(n i-1)) /(N(N-1))$, Where, $\mathrm{ni}=$ the total number of birds of each individual species and $\mathrm{N}=$ the total number of birds of all species. The value of $\mathrm{D}$ ranges between 0 and 1 . With this index, 1 represents infinite diversity and 0 , no diversity. Sørensen similarity index was used to compare the similarity of bird species between terrestrial and aquatic habitats. It measures similarity in species composition Magurran [3] for two sites, A and $B$, by the Equation: $C s=2 a b /(a+b)$, Where, $a$ is the number of species found in site $A ; b$ is the number of species in site $B$ and $\mathrm{ab}$ is the number of species shared by the two sites.

\section{Result}

\section{Identifying water bird habitats in the islands}

The ecological requirements of water birds include the need for island habitat for a range of activities including: feeding, breeding, nesting and protection from predators. It is therefore important to have a good understanding of the ecological requirements of the water birds which use the island, or may be attracted to the island in order to provide suitable habitat for these species. The habitats of Karun River Islands divided as fallow: Islands are used as breeding sites for a number of species that nest on the ground. Waders and terns also commonly use these areas as roosts for 'loafing.

\section{Mudflats and shallow water around the islands}

Are rich feeding areas for a range of migratory waders such as the Red shank. Common Sandpiper and the Little Ringed Plover who probe the water and flats for tiny animals. Larger water birds with long legs and bills such as the egrets, spoonbill, avocet, stilt, heron, and the white-tailed Plover can be found in the shallows probing, spearing, sieving and scooping for food. Little and Swift Terns fly over the water and pluck their prey from above, while the Grey Teal and Mallard dive for their food in the shallows.

\section{Emergent sedges, rushes and grassy bank areas}

Attract many wading birds. Vegetation of this type provides cover for water birds such as the Moorhen and Black-winged Stilt and nesting sites for the Little Tern and the predatory Marsh Harrier. Crakes, rails and various song birds, such as the Turdidae species and Reed Warbler are attracted to the rushes in fresh water around the islands. Moorhens and coots will use open water for loafing and feed in emergent vegetation and grassy bank areas. Ibis, herons and waders are also attracted to fringing bulrushes as feeding areas.

\section{Deep open water in Karun River}

Attracts diving water birds such as coots, cormorants and grebes which dive for bottom-dwelling animals or aquatic vegetation. Other water birds such as terns feed on fish close to the surface.

\section{Bird species composition and relative frequency}

A total of 5218 individuals were observed and recorded in and around Karun river islands (Tables 1 \& 2). Family Ardeidae had the highest number of bird species (seven species) followed by culombidae (five species), Motacillid aeploceidae (four species) each and Charadriidae, Apudidae, Alcedenidae, Meropidae, (three spacie) each, Phalacrocoracidae, Laridae, Scolopacidae, Coraciidae, (tow species) each. Family Sternidae, Rallidae, Treskiornitidae, Lanidae, Pycnonotidae, Timalidae Sturnidae and Hypocolidae had only one species each. There was greater variation in species composition between terrestrial and aquatic habitats. Terrestrial habitat contributed much in terms of species composition (65\%) than aquatic habitat (35\%). We observed that terrestrial habitat had higher number of birds (2587 individuals, 64.91\%) than water birds (1933 individuals, 34.09\%). However, in overall abundance, Little Egret (Egrettagarzetta) had the highest relative frequency (17.11\%) followed by Cattle Egret (Bubulcus ibis) 11.65\%, Scrub Sparow (Passer moabiticus) $8.95 \%$, Rock Sparow (Petroniapetronia) 7.36\% and House sparrow (Passer domesticus) 5.04\% and other species of birds had the lowest relative frequency of less that $3 \%$. Higher relative frequency of birds could be contributed by high frequency of occurrences to some of the birds in different sites. It was observed that Karun river islands has attracted many bird species from local to migratory birds to roost, forage and nest in the area.

The most of birds observed during this study were resident and migratory species. Behrouzi-Rad [4] reported that the species that are spring migrants use islands for nest and other 
activities while waiting for the favorable condition of their home range Behrouzi-Rad [5]. Also, higher number of birds in terrestrial habitat may be attributed to the terrestrial habitat having greater resources such as food and nesting sites and a resulting ability to support more birds Remsen and Parker, Walwert et al. [6,7]. It was observed that certain grass species produced seeds which attracted grain-eating birds for example Passer ssp and Warblers. To inhabiting the area. Trees such Table 1: Birds of 57 species recorded at KRI on April-September 2014.

\begin{tabular}{|c|c|c|c|c|c|c|c|c|c|c|c|c|}
\hline Family & Species & April & May & June & $\begin{array}{l}\text { Spring } \\
\text { Total }\end{array}$ & July & Aug & Sep & $\begin{array}{l}\text { Summer } \\
\text { Total }\end{array}$ & $\begin{array}{c}6 \\
\text { month } \\
\text { Total }\end{array}$ & $\%$ & $\begin{array}{l}\text { Density } \\
\text { bird-1 }\end{array}$ \\
\hline \multirow[t]{3}{*}{$\begin{array}{l}\text { Phalacroco- } \\
\text { racidae }\end{array}$} & $\begin{array}{c}\text { Great Cormorant } \\
\text { Phalacrocoraxcarbo }\end{array}$ & 38 & 8 & 0 & 46 & 20 & 0 & 0 & 20 & 66 & 1.26 & 6.6 \\
\hline & $\begin{array}{c}\text { Pygmy cormorant } \\
\text { Phalacro-coraxpygmeus }\end{array}$ & 8 & 4 & 2 & 14 & 0 & 0 & 0 & 0 & 14 & 0.26 & 1.4 \\
\hline & $\begin{array}{c}\text { Black-headed } \\
\text { GullLarusridibundus }\end{array}$ & 125 & 43 & 8 & 176 & 27 & 90 & 74 & 191 & 367 & 7.03 & 36.7 \\
\hline \multirow[t]{2}{*}{ Laridae } & $\begin{array}{l}\text { Slender-billed } \\
\text { GullLarusgenei }\end{array}$ & 87 & 98 & 21 & 206 & 1 & 12 & 9 & 22 & 228 & 4.36 & 22.8 \\
\hline & $\begin{array}{l}\text { Great Black-headed } \\
\text { GullLarusichthyaetus }\end{array}$ & 12 & 0 & 2 & 12 & 0 & 0 & 0 & 0 & 14 & 0.26 & 1.4 \\
\hline Sternidae & $\begin{array}{c}\text { Little Tern } \\
\text { Sterna albifrons }\end{array}$ & 3 & 0 & 0 & 3 & 0 & 0 & 0 & 0 & 3 & 0.05 & 0.3 \\
\hline Rallidae & $\begin{array}{c}\text { Moorhen } \\
\text { Gallinula Chloropus }\end{array}$ & 4 & 2 & 0 & 6 & 0 & 0 & 0 & 0 & 6 & 0.11 & 0.6 \\
\hline \multirow[t]{3}{*}{4 Family } & 7 Species Total & 277 & 155 & 33 & 456 & 48 & 102 & 83 & 233 & 689 & 13.37 & 68.9 \\
\hline & $\begin{array}{l}\text { Great White Heron } \\
\text { Cosmerodiusalbus }\end{array}$ & 2 & 1 & 2 & 5 & 0 & 0 & 0 & 0 & 5 & 0.09 & 0.5 \\
\hline & $\begin{array}{c}\text { Little Egret } \\
\text { Egrettagarzetta }\end{array}$ & 153 & 281 & 231 & 665 & 118 & 98 & 12 & 228 & 893 & 17.11 & 89.3 \\
\hline \multirow[t]{4}{*}{ Ardeidae } & $\begin{array}{c}\text { Black-crowned } \\
\text { Night Heron Nycticora- } \\
\text { xnycticorax }\end{array}$ & 38 & 19 & 1 & 48 & 85 & 69 & 42 & 196 & 254 & 4.86 & 25.4 \\
\hline & $\begin{array}{l}\text { Cattle Egret } \\
\text { Bubulcus ibis }\end{array}$ & 121 & 156 & 187 & 464 & 91 & 43 & 10 & 144 & 608 & 11.65 & 60.8 \\
\hline & $\begin{array}{l}\text { Grey Heron } \\
\text { Ardeacinerea }\end{array}$ & 8 & 7 & 8 & 23 & 3 & 1 & 1 & 5 & 28 & 0.53 & 2.8 \\
\hline & $\begin{array}{l}\text { Squacco Heron } \\
\text { Ardeolaraloides }\end{array}$ & 2 & 2 & 3 & 7 & 37 & 6 & 6 & 49 & 56 & 1.07 & 5.6 \\
\hline $\begin{array}{l}\text { Treskior- } \\
\text { nithidae }\end{array}$ & $\begin{array}{c}\text { Spoonbill } \\
\text { Platalealeucorodia }\end{array}$ & 2 & 0 & 0 & 2 & 0 & 0 & 0 & 0 & 2 & 0.03 & 0.2 \\
\hline \multirow[t]{2}{*}{$\begin{array}{l}\text { Recorvi- } \\
\text { rostridae }\end{array}$} & $\begin{array}{c}\text { Black-winged Stilt } \\
\text { Himantopushimantopus }\end{array}$ & 5 & 3 & 6 & 14 & 4 & 8 & 3 & 15 & 29 & 0.55 & 2.9 \\
\hline & $\begin{array}{l}\text { Common sandpiper } \\
\text { Actitishypoleucos }\end{array}$ & 3 & 4 & 1 & 8 & 5 & 6 & 5 & 16 & 24 & 0.46 & 2.4 \\
\hline \multirow[t]{2}{*}{ Charadriidae } & $\begin{array}{l}\text { White-tailed Polver } \\
\text { Chettusialeucura }\end{array}$ & 4 & 3 & 1 & 8 & 1 & 0 & 0 & 1 & 9 & 0.17 & 0.9 \\
\hline & $\begin{array}{l}\text { Little-ringed Plover } \\
\text { Charadriusdubius }\end{array}$ & 2 & 1 & 2 & 5 & 2 & 0 & 1 & 3 & 8 & 0.15 & 0.8 \\
\hline \multirow[t]{2}{*}{ Scolopacidae } & $\begin{array}{l}\text { Red-wattled Lapwing } \\
\text { Hoplopterusindicus }\end{array}$ & 1 & 3 & 0 & 4 & 2 & 2 & 3 & 7 & 11 & 0.21 & 1.1 \\
\hline & $\begin{array}{c}\text { Redshank } \\
\text { Tringatotanus }\end{array}$ & 2 & 1 & 1 & 2 & 2 & 0 & 0 & 2 & 6 & 0.11 & 0.6 \\
\hline 5 Family & 13 species Total & 343 & 481 & 443 & 1267 & 350 & 233 & 83 & 666 & 1933 & 37.04 & 193.3 \\
\hline
\end{tabular}


International Journal of Environmental Sciences \& Natural Resources

\begin{tabular}{|c|c|c|c|c|c|c|c|c|c|c|c|c|}
\hline & $\begin{array}{c}\text { Palm Dove } \\
\text { Streptopeliasengalensis }\end{array}$ & 32 & 23 & 12 & 66 & 15 & 16 & 9 & 40 & 107 & 2.05 & 21.4 \\
\hline \multirow[t]{5}{*}{ Culombidae } & $\begin{array}{c}\text { Turtule Dove } \\
\text { Streptopeliaturtur }\end{array}$ & 23 & 32 & 18 & 73 & 18 & 6 & 8 & 32 & 105 & 2.01 & 21 \\
\hline & $\begin{array}{c}\text { Collared Dove } \\
\text { Streptopeliadecaocta }\end{array}$ & 24 & 18 & 21 & 63 & 18 & 9 & 11 & 38 & 101 & 1.94 & 20.2 \\
\hline & $\begin{array}{c}\text { Woodpegion } \\
\text { Culombapalombus }\end{array}$ & 34 & 36 & 28 & 98 & 18 & 6 & 9 & 33 & 131 & 2.51 & 26.2 \\
\hline & Rock Dove Culombalivia & 4 & 3 & 2 & 9 & 2 & 2 & 2 & 6 & 15 & 0.29 & 3 \\
\hline & Pallid Swift Apuspallidus & 60 & 21 & 0 & 81 & 23 & 6 & 17 & 46 & 127 & 2.43 & 25.4 \\
\hline \multirow[t]{3}{*}{ Apudidae } & House Swift Apusaffinis & 34 & 23 & 25 & 82 & 14 & 0 & 0 & 14 & 96 & 1.84 & 19.2 \\
\hline & Alpian Swift Apus melba & 43 & 6 & 13 & 62 & 7 & 0 & 0 & 7 & 69 & 1.32 & 13.8 \\
\hline & $\begin{array}{l}\text { Smyran Kingfisher } \\
\text { Halcyon smyrnensis }\end{array}$ & 0 & 0 & 3 & 3 & 6 & 4 & 5 & 15 & 18 & 0.34 & 3.6 \\
\hline \multirow[t]{3}{*}{ Alcedinidae } & $\begin{array}{c}\text { Lesser Pied Kingfisher } \\
\text { Cerylrudis }\end{array}$ & 3 & 2 & 4 & 9 & 12 & 8 & 9 & 29 & 38 & 0.73 & 7.6 \\
\hline & Kingfisher Alcedoatthis & 1 & 2 & 2 & 5 & 2 & 1 & 1 & 4 & 9 & 0.17 & 1.8 \\
\hline & $\begin{array}{c}\text { Bee-eater } \\
\text { Meropsapiaster }\end{array}$ & 13 & 8 & 7 & 28 & 3 & 1 & 0 & 4 & 32 & 0.61 & 6.4 \\
\hline \multirow[t]{3}{*}{ Meropidae } & $\begin{array}{l}\text { Blue-cheeked Bee-eater } \\
\text { Meropssuperciliasus }\end{array}$ & 4 & 6 & 2 & 12 & 1 & 0 & 0 & 1 & 13 & 0.25 & 2.6 \\
\hline & $\begin{array}{l}\text { Little Green Bee-eater } \\
\text { Meropsorientalis }\end{array}$ & 6 & 6 & 4 & 16 & 0 & 3 & 0 & 3 & 19 & 0.36 & 3.8 \\
\hline & Swallow Hirundorustica & 34 & 20 & 11 & 65 & 12 & 9 & 9 & 30 & 95 & 1.82 & 19 \\
\hline \multirow[t]{2}{*}{ Hirundinidae } & $\begin{array}{l}\text { Pale Carag Martin } \\
\text { Hirundoobsoleta }\end{array}$ & 12 & 13 & 11 & 36 & 6 & 2 & 0 & 8 & 44 & 0.84 & 8.8 \\
\hline & $\begin{array}{c}\text { Sand Martin } \\
\text { Repariariparia }\end{array}$ & 32 & 13 & 11 & 56 & 11 & 0 & 0 & 11 & 67 & 1.28 & 13.4 \\
\hline \multirow[t]{4}{*}{ Motacillidae } & $\begin{array}{l}\text { Pied wagtail } \\
\text { Motacilla alba }\end{array}$ & 1 & 2 & 1 & 4 & 2 & 1 & 2 & 5 & 9 & 0.17 & 1.8 \\
\hline & $\begin{array}{l}\text { Citrine Wagtail } \\
\text { Motacilacitreola }\end{array}$ & 1 & 0 & 0 & 1 & 1 & 1 & 0 & 2 & 3 & 0.6 & 0.6 \\
\hline & $\begin{array}{c}\text { Grey Wagtail } \\
\text { Motacilacinerea }\end{array}$ & 1 & 1 & 1 & 3 & 1 & 0 & 0 & 1 & 4 & 0.7 & 0.8 \\
\hline & $\begin{array}{l}\text { Long-billed Pipit } \\
\text { Anthussimilis }\end{array}$ & 3 & 2 & 0 & 5 & 1 & 0 & 0 & 1 & 6 & 0.11 & 1.2 \\
\hline \multirow[t]{2}{*}{ Coraciidae } & $\begin{array}{c}\text { Indian Roller } \\
\text { Corasiasbenghalensis }\end{array}$ & 0 & 1 & 0 & 1 & 1 & 0 & 1 & 2 & 3 & 0.6 & 0.6 \\
\hline & $\begin{array}{c}\text { Roller } \\
\text { Coraciasgarrulus }\end{array}$ & 1 & 1 & 0 & 2 & 1 & 1 & 0 & 2 & 1 & 0.2 & 0.2 \\
\hline Laniidae & $\begin{array}{l}\text { Red-backed Shrike } \\
\text { Laniuscollurion }\end{array}$ & 0 & 1 & 0 & 1 & 0 & 0 & 0 & 0 & 1 & 0.2 & 0.2 \\
\hline Timaliidae & $\begin{array}{l}\text { Common Babbler } \\
\text { Turdoidescaudatus }\end{array}$ & 1 & 2 & 1 & 4 & 3 & 4 & 2 & 9 & 13 & 0.24 & 2.6 \\
\hline \multirow[t]{3}{*}{ Pycnonotidae } & $\begin{array}{l}\text { White-eared Bulbul } \\
\text { Pycnonotusleucotis }\end{array}$ & 2 & 3 & 4 & 9 & 3 & 4 & 2 & 9 & 18 & 0.34 & 3.6 \\
\hline & $\begin{array}{c}\text { Reed Warbler } \\
\text { Acrocephalusscirpaceus }\end{array}$ & 1 & 1 & 0 & 2 & 0 & 0 & 1 & 1 & 3 & 0.6 & 0.6 \\
\hline & $\begin{array}{c}\text { Graceful Warbler } \\
\text { Priniagracilis }\end{array}$ & 0 & 1 & 0 & 1 & 1 & 0 & 0 & 1 & 2 & 0.3 & 0.8 \\
\hline \multirow[t]{2}{*}{ Sylvidae } & $\begin{array}{l}\text { Desert Warbler } \\
\text { Sylvia nana }\end{array}$ & 5 & 4 & 0 & 9 & 0 & 0 & 0 & 0 & 9 & 0.17 & 1.8 \\
\hline & $\begin{array}{l}\text { Whitethroat } \\
\text { Sylvia Communis }\end{array}$ & 2 & 0 & 0 & 2 & 1 & 0 & 0 & 1 & 3 & 0.6 & 0.6 \\
\hline
\end{tabular}


International Journal of Environmental Sciences \& Natural Resources

\begin{tabular}{|c|c|c|c|c|c|c|c|c|c|c|c|c|}
\hline & $\begin{array}{l}\text { House Sparrow Passer } \\
\text { domesticus }\end{array}$ & 69 & 82 & 56 & 207 & 15 & 12 & 48 & 75 & 282 & 5.04 & 56.4 \\
\hline \multirow[t]{4}{*}{ Passeridae } & $\begin{array}{c}\text { Rock Sparrow } \\
\text { Petroniapetronia }\end{array}$ & 35 & 45 & 31 & 111 & 131 & 21 & 85 & 237 & 348 & 7.36 & 76.8 \\
\hline & $\begin{array}{c}\text { Spanish Sparrow Passer } \\
\text { hispaniolensis }\end{array}$ & 45 & 43 & 23 & 111 & 15 & 12 & 18 & 45 & 156 & 2.99 & 31.2 \\
\hline & $\begin{array}{c}\text { Scrub Sparrow Passer } \\
\text { moabiticus }\end{array}$ & 120 & 123 & 112 & 355 & 45 & 37 & 27 & 109 & 467 & 8.95 & 93.4 \\
\hline & $\begin{array}{c}\text { Pale Rock Sparrow } \\
\text { Petroniabrachydactyla }\end{array}$ & 43 & 23 & 28 & 94 & 23 & 17 & 23 & 63 & 157 & 3.00 & 31.4 \\
\hline Hypocollidae & $\begin{array}{l}\text { Grey Hypocolius } \\
\text { Hipocoliusampelinus }\end{array}$ & 2 & 2 & 2 & 6 & 0 & 0 & 0 & 0 & 6 & 0.11 & 1.2 \\
\hline Sturnidae & $\begin{array}{c}\text { Common Mynah } \\
\text { Acridotherestristris }\end{array}$ & 2 & 1 & 2 & 5 & 2 & 1 & 2 & 5 & 10 & 0.19 & 2 \\
\hline \multirow[t]{4}{*}{$\begin{array}{c}\text { Terresterial } \\
\text { family } 15\end{array}$} & Terrestrial species 37 & & & & & & & & & & & \\
\hline & Total of terrestrial birds & 693 & 570 & 435 & 1698 & 414 & 184 & 291 & 889 & 2587 & 49.57 & 517.4 \\
\hline & Total species & & & & 57 & & & & 47 & & & \\
\hline & $\begin{array}{l}\text { Total Specie every } \\
\text { month }\end{array}$ & 53 & 51 & 43 & - & 47 & 34 & 32 & - & - & - & - \\
\hline \multirow[t]{3}{*}{ Family 24} & $\begin{array}{l}\text { Species Density } \mathrm{h}^{-1} \text { in } 15 \\
\text { hectare }\end{array}$ & 3.53 & 3.4 & 2.8 & 3.8 & 3.1 & 2.26 & 2.13 & 3.13 & - & - & - \\
\hline & Total Avifauna Count & 1313 & 1206 & 911 & 3430 & 812 & 519 & 457 & 1788 & 5218 & & \\
\hline & $\begin{array}{c}\text { population density } \\
\text { bird }^{-1}(\text { in } 15 \text { Hectare })\end{array}$ & 87.533 & 80.40 & 60.73 & 228.66 & 54.13 & 34.6 & 30.46 & 119.2 & 347.86 & & \\
\hline
\end{tabular}

Table 2: Bird species composition, richness and diversity.

\begin{tabular}{|c|c|c|c|}
\hline Parameter & Terrestrial birds & Waterbirds & Both terrestrial and waterbirds \\
\hline Number of individuals & 3430 & 1788 & 5218 \\
\hline Species richness & 37 & 20 & 57 \\
\hline Number of families & 24 & 9 & 100 \\
\hline Proportional by habitat (\%) & 65.73 & 34.27 & $2 . .75$ \\
\hline Shannon's diversity index & 2.2745 & 2.2391 & 0.9123 \\
\hline Simpson's diversity index & 0.8407 & 0.8330 & 23 \\
\hline
\end{tabular}

The higher abundance of birds in terrestrial habitat could also be due to the composition of the vegetation that forms the main element of their habitat Lee and Rotenberry, Chapman and Reich, Salah and Idris [10-12]. The lower number of water birds could be attributed to the destruction of the islands habitats, due to grass and tree cutting, recreation, and cultivation. The riverine vegetations around the islands were observed to be heavily overgrazed by cattle which use the areas around the islands as feeding areas and vegetation cleared due to cultivation thus interfering with the area which could be used for nesting, feeding, and breeding sites for wetland birds. A study conducted in Niger by Brouwer et al. [13] revealed that the most important threat for White storks (Ciconiaciconia) was the degradation of wetlands which were ideal habitats for roosting and thermoregulation.
The reduction of bird population may have been contributed by degradation of islands and the loss of suitable upland habitats that surround wetland making no value to wetland dependent birds Bellrose and Trudeau [14]. We hypothesized that there was no difference between the terrestrial and wetland habitats in terms of bird species diversity. However, although there was a difference in numbers of bird species between the terrestrial and wetland habitats when making comparison, the Sorensen's Similarity index was 39\% suggesting that both terrestrial and aquatic habitats are different in terms of birds' species composition. The little observed deviation in species composition could be mainly due to disturbance on islands areas (recreation and cultivation around on the big islands) and seasonal change; the flooded river does not favor other species of water birds, which their feeds depend mostly on shallow water. 


\section{Bird species diversity}

A total 57 species were recorded during the study period comprising of 37 and 20 species of terrestrial birds and water birds respectively. Species richness of different feeding guilds might respond differently to changes in vegetation structure and complexity across tropical ecosystems Waltert et al. [15]. Shannon's diversity index indicate that terrestrial habitat had higher species diversity $\left(\mathrm{H}^{\prime}=2.27\right)$ than aquatic habitat $\left(\mathrm{H}^{\prime}=\right.$ 2.23). The overall birds' diversity for both terrestrial and aquatic was 2.75 (Table 3). On the other hand, the Simpson's diversity index for terrestrial birds and water birds were 0.84 and 0.83 respectively. However, the overall Simpson's diversity index for the two habitats was 0.91 . This indicates greater variation in species diversity between the results obtained by using Shannon's and Simpson's diversity indices. This is because Simpson's diversity index takes into consideration relative abundance which is not the case for Shannon's diversity index (Table 4).

Table 3: The monthly density of water birds and terrestrial birds at $\mathrm{KRI}$ in six.

\begin{tabular}{|c|c|c|}
\hline Monthly density & $\begin{array}{l}\text { Density estimate of } \\
\text { terrestrial birds } \mathbf{h}^{-1}\end{array}$ & $\begin{array}{l}\text { Density estimate of } \\
\text { water birds } h^{-1}\end{array}$ \\
\hline April & 262.6 & 62 \\
\hline May & 241.2 & 63.1 \\
\hline June & 182.2 & 47.6 \\
\hline July & 162.4 & 39 \\
\hline August & 103.8 & 33.5 \\
\hline September & 91.4 & 16.6 \\
\hline Average & 173.93 & 43.63 \\
\hline
\end{tabular}

Table 4: Bioindexes of birds in and around of Karun river islands.

\begin{tabular}{|c|c|c|}
\hline & Terrestrial Birds & Waterbirds \\
\hline Dominance_D & 0.15915 & 0.166975 \\
\hline Simpson_1-D & 0.84085 & 0.833025 \\
\hline Shannon_H & 2.2745 & 2.2379 \\
\hline Evenness_e^H/S & 0.444883 & 0.444297 \\
\hline Brillouin & 2.1555 & 2.114083 \\
\hline Menhinick & 1.275917 & 1.290403 \\
\hline Margalef & 3.754167 & 3.686028 \\
\hline Equitability_J & 0.735517 & 0.731986 \\
\hline Fisher_alpha & 5.614667 & 5.540611 \\
\hline Berger-Parker & 0.3113 & 0.324417 \\
\hline Chao-1 & 26.48333 & 25.69722 \\
\hline
\end{tabular}

The higher diversity in terrestrial habitat may be due to high numbers of individuals in some of bird species (16 species had above 20 individuals) compared to water bird species (only 6 species which had individuals above 20 individuals) and diverse vegetation types as microhabitats which favored varieties of bird species. Vegetation cover has been reported to have a strong influence on avifauna diversity Scott Mills, Radford [16,17] it was expected that the bird diversity in and around Karun River islands would vary following the habitat difference. Overall, the findings of the present study support this prediction. Vegetation variety is among the factor which bird diversity in tropical Africa depends on Yallop et al. [18] Also, the high diversity in terrestrial habitat could be due to high number of few bird species such as Passer moabiticus which accounted for $8.95 \%$ of all individual birds.

It was observed that livestock grazing and fishing were the main illegal activities in and around the Karun river big islands and this might be of detrimental effect to bird species diversity in the long term. The lower number of bird species at around islands could be due to the flooding of the Karun river since birds were found only on patches of shallow water where birds were able to get forage. This situation limited some of the bird species which were unable to forage in deep water (Waders and wading birds). Bird species shift their feeding habit between seasons Rad ward [19]. Also, the presence of high number of bird species in terrestrial habitats could be due to the presence of varieties of microhabitats which provide niche for different species of birds. The area had different patches of habitats ranging from grasslands, shrublands, and wooded shrublands and riverine vegetation, thus providing multiple and varieties of alternative food and roost for birds.

\section{Dominance species}

A total of 57species were observed and recorded in and around Karun river islands covering both, terrestrial and water habitats. Dominance results when one or several species control the environment and conditions that influence associated species. The results indicate that overall 10 bird species dominated the area in terms of relative abundance (Table 1). It was revealed that Little Egret was the most dominant (17.11\%) followed by Cattle Egret (11.65\%),Black-headed Gull, (7.03\%), Blackcrowened Night Heron (4.86\%) ,Slender-billed Gull (4.36\%), Great Cormorant ( $1.26 \%$ ), and Squacco Heron (1.07\%), while the remaining species of water birds had less than $1 \%$. in Karun River ecosystem. About ten different bird species were found to dominate the terrestrial habitat in terms of relative abundance (Table 1). Scrub Sparrow was the most dominant bird species (8.95\%\%), followed by Rock Sparrow (7.36\%), House Sparrow $5.4 \%$, and Spanish Sparrow had 2.99\%. The dominance of these species could be contributed by high encounter rates and the presence favorable habitats in Karun river islands. The availability of food makes some birds with a feeding guild of a highly abundant food to dominate the area.

\section{Conclusion}

The study concluded that K.R.I. is very important to the bird communities. Family Ardeidae had the highest number of bird species followed by Columbidae, Motacilidae, Plociedae, 
Sylvidae, Apudidae. Family Sternidae, Rallidae, Treskiornitidae, Recorvirostridae, Lanidae, Timalidae, Hypoculidae, Sturnidae and Pycnonotidae had only one species each. There was greater variation in species composition between terrestrial and aquatic habitats. Terrestrial habitat contributed much in terms of species composition than aquatic habitat. Ploceidae had the highest abundance in terms of frequency followed by Ardeidae higher relative abundance of birds could be contributed by high frequency of occurrences to some of the birds in different sites. Little Egret accounted for $17.11 \%$ of all birds.

The K.R.I could have more bird species if intentional measures are taken to manage the area from anthropogenic activities that threaten the life of avifauna. Habitat destruction could have a net negative effect on the population of water and terrestrial birds. Thus, if the amount and quality of wetland habitat is substantially reduced, populations of wetlanddependent birds in the area also can be expected to decrease. Further studies to cover winter season and nocturnal birds to generate a comprehensive list of bird species diversity in and around K.R.I are vital. Land use planning that both protects the islands and emphasizes bird-friendly landscape design around K.R.I may enhance avian diversity and abundance within the area. On the other hand, the islands are important place for bird watchers in Ahvaz city, because the birdwatchers can observe and enjoy every time in the islands by watching to the colonial water birds, waders, wading birds and terrestrial birds in islands. In Karun river at around of the island birdwatcher can see the Herons, Egrets and Gulls during the day. In the island they can watch to sung and perching birds during a day. Density, diversity and population composition of birds in and around of the Karun river islands make them the nearest and beautiful place for bird watchers.

\section{Management}

The following management practices could be considered for inclusion in the island management:

Place branches and large logs around the edge of the islands at varying heights, to provide roosting and nesting sites.

Provide for a range of water depths. Link shallow mudflats to an island rather than the shore to provide secure habitat for waders.

Use natural edges with slopes of between 1:4 and 1:15, rather than steep banks. The provision of vegetated banks and some bare areas will provide birds with access in and out of the islands and will allow them to see predators.

Eradicate weeds as they can spread rapidly in and around islands and have the potential to degrade water bird habitat and reduce food resources.

Revegetate the islands to restore water bird habitat by replanting existing vegetation types that are found around the islands.
Fencing can be used to limit access to livestock, and thus reduce bank erosion and disturbance to fringing vegetation. This will also allow natural regeneration in disturbed areas.

Maintain mature trees around islands to provide habitat for birds and small animals. A number of water birds such as the Herons, the Egrets and the sparrows for nests.

\section{Suggestion}

If boats are permitted to be used on the ground of islands concerned, minimize damage to fringing vegetation by only launching boats at established launch sites.

Be careful not to disturb feeding and nesting birds. Watch from a distance.

Only passive recreational activities should be permitted in spring when most water birds breed.

\section{Acknowledgment}

This research project has been financially supported by the Khouzestan Science and Research Branch, Islamic Azad University in 2014, and I am very grateful to the Research deputy of Kouzestan Science and Research Branch, Islamic Azad University, for their advice and in particular to Dr Gholami for his active assistance. In particular, we are indebted to Dr HeydariNajad (Former Research Deputy) for his supports of the research project on the islands of Karun River in 2014.

\section{References}

1. Balla S, (2013) Wetlands of the Swan Coastal Plain 1 Their nature and management. Water Authority of Western Australia and the Department of Environmental Protection, Australia 1(1): 21-23.

2. Bibby CJ, Burgress ND, Hill DA, Mutoe S (2000) Bird census Techniques. British trust for ornithological and Royal society for protection of birds. 2nd ed. Academic press, London pp. 317.

3. Magurran A (2004) Measuring biological diversity. Oxford, UK: Blackwell Publishing.

4. Behrouzi-Rad (2013) Egretta gularis and four Tern species on Ghaber Nakhoda Island (Persian Gulf) in 2003 and 2012. International Journal of Marine Science 3(42): 344-351.

5. Behrouzi-Rad B (2013) Investigation of avifauna of Karun river Islands for attracting bird watchers, Unpublished report, Khouzestan Science and Research Branch, Ahvaz pp. 131

6. Remsen JV, Parker III TA (1983) Contribution of river-created habitats to bird species richness in Amazonia. Biotropica 15(3): 223-231.

7. Walwert M, Mardiastuti A, Muhlenberg M (2004) Effects of land use on bird species richness in Sulawesi, Indonesia. Conserv. Biol 18(5): 1339-1346.

8. Petersen KL, Westmark AS (2013) Bird Use of Wetlands in a Midwestern Metropolitan Area in Relation to Adjacent Land Cover. Am Midl Nat 169(1): 221-228.

9. Welsh DA (1987) Birds as indicators of forest stand condition in bored forest of eastern Canada. In: Diamond AW and Filion FL. The value of Birds. International council for Bird preservation. Cambridge, England. pp. 259-266.

10. Lee PY, Rotenberry JT (2005) Relationships between bird species 
and tree species assemblages in forested habitats of eastern North America. J Biogeogr. 32(7): 1139-1150.

11. Chapman KA, Reich PB (2007). Land use and habitat gradients determine bird community diversity and abundance in suburban, rural and reserve landscapes of Minnesota, USA. Biol Conser 135: 527-541.

12. Salah 0, Idris E (2013) A note on the bird diversity at two sites in Khartoum, Sudan Egypt. Acad J Biol Sci 5(1): 1-10.

13. Brouwer J, Mullié WC, Scholte P (2003) White storks Ciconiaciconia wintering in Chad, northern Cameroon and Niger Querner Ibis 145: 499-501.

14. Bellrose FC, Trudeau NM (1988) Wetlands and their relationship to migrating and winter populations of waterfowl : Portland, Oreg, Timber Press. pp. 183-194.

15. Waltert M, Bobo KS, Sainge NM, Fermon H, Mühlenberg M (2005) From forest to farmland: habitat effects on Afrotropical forest bird diversity. Ecol Appl 15(4): 1351-1366.

16. Scott Mills G, Dunning JB, Bates JM (1989). Effects of urbanization on breeding bird community structure in southwestern desert habitats. Condor 91(2): 416-428.

17. Ward P (1969) The annual cycle of the Yellow-vented Bulbul. Pycnonotusgoiavier, in a humid equatorial environment. J Zool 157(1): $25-45$

18. Yallop ML, Connell MJ, Bullock R (2003). Water birds Herbivory on a newly created wetland complex: Potential implication for site management and habitat creation. Wetl. Ecol. Manage. 12(5): 395-408.

19. Radford JQ Bennett AF, Cheers GJ (2005). Landscape-level thresholds of habitat cover for woodland-dependent birds. Biol. Conserv 124: 317-337.

\section{Your next submission with Juniper Publishers will reach you the below assets}

- Quality Editorial service

- Swift Peer Review

- Reprints availability

- E-prints Service

- Manuscript Podcast for convenient understanding

- Global attainment for your research

- Manuscript accessibility in different formats

( Pdf, E-pub, Full Text, Audio)

- Unceasing customer service

Track the below URL for one-step submission https://juniperpublishers.com/online-submission.php 